\title{
The imperative for neurology educational research
}

\author{
Barney J. Stern, MD; and Susan K. Rodmyre
}

The American Academy of Neurology (AAN) has determined that there is a need within the neurologic community to critically study the effectiveness of neurologic educational programs to ensure that they are meeting the needs of their constituents, including medical students, residents, fellows, and practicing neurologists. The AAN has also recognized the importance of strengthening its educational programs for quality improvement and credentialing purposes, as well as a need to train neurologic educators to perform and publish education research as one component of career development. The AAN Education Committee, together with the leadership of the AAN, brought these needs to the forefront during the AAN Education Committee strategic planning process. The AAN Education Committee further formed the Education Research Work Group (ERWG) to facilitate such education research.

The AAN defines Education Research as the qualitative and quantitative study of hypothesisdriven observations or interventions on the acquisition of knowledge or training. The ERWG has identified two primary goals of education research: 1) improving the education for members, residents, students, nonneurologists, and academic educators; and 2) promoting career development for neurologic educators.

The AAN educational research grant effort launched in July 2006 is one of the first steps the AAN is taking in achieving its goals. Requests for grant applications were solicited starting on June 26, 2006 , with a due date of September 12,2006 . Up to four applications will be funded from a total pool of $\$ 20,000$. Successful applicants will be funded for 1 year beginning in early 2007. It is hoped that these awards will lead to a sustainable initiative in education research.

The ERWG has also initiated a process to tag each educational offering of the AAN with core competency labels. It is hoped that these identifiers will not only assist physicians in selecting educational offerings, but will also facilitate research projects. A critical challenge to educational programs has been to assess the impact of educational programs on physician behavior. The core competency tags may prove valuable for outcomes assess- ment of education programs as well as individual physician requirements for maintenance of certification.

There are numerous education research opportunities for residents and fellows. These might include projects related to defining optimal teaching and educational strategies, patient safety, enhancing professionalism, and correlating resident or fellow accomplishments with future career success. The introduction of the American Board of Psychiatry and Neurology's directive for the assessment of clinical competency with five required patient evaluations, and the concurrent ending of the traditional "oral boards," is a unique opportunity for research initiatives.

We invite residents and fellows to initiate education research projects. They are in a unique point in their careers to benefit themselves and future colleagues by their findings. Residents can partner with faculty to respond to future AAN funding opportunities. The AAN's support of education research will hopefully grow as the accomplishments of education researchers impact all neurologists. 


\title{
Neurology
}

\author{
The imperative for neurology educational research \\ Barney J. Stern and Susan K. Rodmyre \\ Neurology 2006;67;1521 \\ DOI 10.1212/01.wnl.0000243250.73853.94
}

This information is current as of October 23, 2006

\section{Updated Information \&} Services

Citations

Permissions \& Licensing

Reprints including high resolution figures, can be found at: http://n.neurology.org/content/67/8/1521.full

This article has been cited by 3 HighWire-hosted articles: http://n.neurology.org/content/67/8/1521.full\#\#otherarticles

Information about reproducing this article in parts (figures,tables) or in its entirety can be found online at:

http://www.neurology.org/about/about_the_journal\#permissions

Information about ordering reprints can be found online: http://n.neurology.org/subscribers/advertise

Neurology ${ }^{\circledR}$ is the official journal of the American Academy of Neurology. Published continuously since 1951, it is now a weekly with 48 issues per year. Copyright. All rights reserved. Print ISSN: 0028-3878. Online ISSN: 1526-632X.

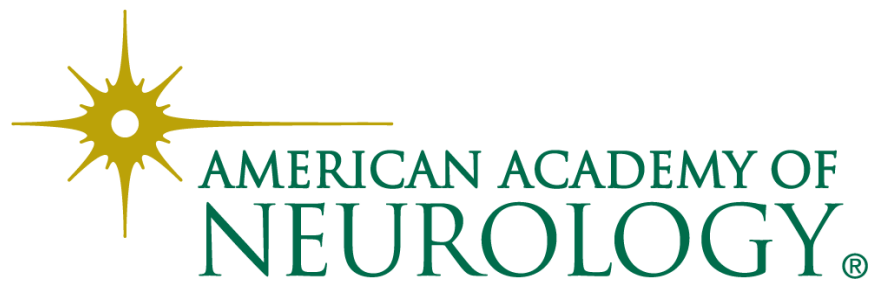

